\title{
Kinetics Study of Oil Extraction from Calophyllum inophyllum Seeds Using Ultrasonic-assisted Extraction Technique
}

\author{
Faiznur Mohd. Fuad ${ }^{1}$ and Khairiah Abd. Karim²* \\ ${ }^{1}$ Faculty of Chemical Engineering, Universiti Teknologi MARA, \\ 40450 Shah Alam, Selangor, Malaysia \\ ${ }^{2}$ School of Chemical Engineering, Universiti Sains Malaysia, Engineering Campus, \\ 14300 Nibong Tebal, Pulau Pinang, Malaysia \\ *Corresponding author: chkhairiah@usm.my
}

Published online: 15 August 2017

To cite this article: Mohd. Fuad, F. \& Abd. Karim, K. (2017). Kinetics study of oil extraction from Calophyllum inophyllum seeds using ultrasonic-assisted extraction technique. $J$. Phys. Sci., 28(2), 57-69, https://doi.org/10.21315/jps2017.28.2.4

To link to this article: https://doi.org/10.21315/jps2017.28.2.4

\begin{abstract}
In this study, the oil from Calophyllum inophyllum seeds was extracted using ultrasonic-assisted extraction (UAE) technique. Patricelli's model was used to evaluate the kinetics of oil extraction process in which this model describes extraction in two stages namely rapid washing stage followed by slow diffusion stage. The model parameters were calculated using the experimental data. A good agreement was observed between the experimental and simulated oil yield in all experiments (R20.974), indicating that Patricelli's model was adequate to describe the C. inophyllum seeds oil extraction process. In addition, the influence of three extraction parameters, namely ultrasonic power, extraction temperature and liquid to solid $(L / S)$ ratio on oil yield were studied. It was found that the oil yield increased with increasing ultrasonic power, extraction temperature as well as $L / S$ ratio.
\end{abstract}

Keywords: Calophyllum inophyllum, ultrasonic-assisted extraction, seed oil, kinetics, Patricelli

\section{INTRODUCTION}

Calophyllum inophyllum Linn. (C. inophyllum), as shown in Figure 1, is a beautiful plant native to India, East Africa, South East Asia, Australia and South Pacific. ${ }^{1}$ The plant is widespread from the Indian Ocean (Africa and India) throughout Malaysia and in the Pacific islands. ${ }^{2}$ This tree belongs to the Clusiaceae (Guttifereae) 
family. ${ }^{3}$ It is also known as Penaga Laut, Tamanu, Alexandrian Laurel, Bintangor, Nyamplung and Kamani. ${ }^{4-6}$ C. inophyllum is well known for its oil-bearing seeds which contain up to $75 \%$ oil content. The oil was one of the oldest known to be used for illumination in India and across the Pacific. ${ }^{7}$ The pain-relieving properties of $C$. inophyllum oil has been used traditionally to relieve rheumatism, joint pains and haemorrhage. ${ }^{8}$ In addition, it is also used for treating various skin diseases including scabies, ringworm and dermatosis. ${ }^{3}$ Recently, $C$. inophyllum oil has been recognised as a potential source for biofuel. ${ }^{9}$ Even though $C$. inophyllum seeds are widely known for being a highly potential alternative source of vegetable oil, these seeds are still under-utilised and less exploited, particularly in Malaysia.
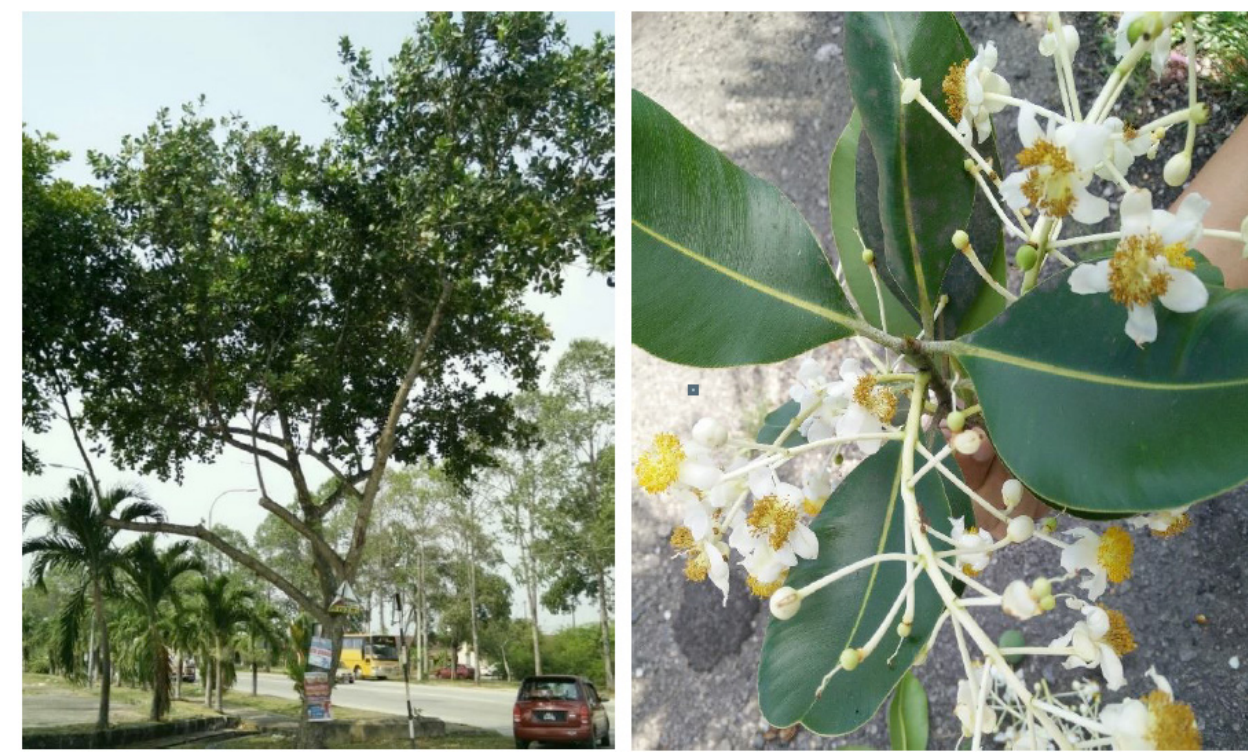

Figure 1: C. inophyllum tree, leaves and flowers.

According to Sayyar et al., the main factors that influence solid-liquid extraction performance are type of solvent, operating temperature of the process, reaction time between solvent and seeds as well as the ratio of solvent to seeds. ${ }^{10}$ JovanovicMalinovska et al. have reported that ultrasonic-assisted extraction (UAE) provided an increased extraction yield, increased rate of extraction, reduced extraction time and higher processing throughput. ${ }^{11}$ In fact, it requires less solvent volume and low extraction temperature which was advantageous for the extraction of heat labile compounds. In recent years, UAE was used widely in the extraction of oil from various types of seeds including hemp, papaya and tomato seeds. ${ }^{12-14}$

The extraction performance in UAE was enhanced by cavitation. During cavitation, the bubbles developed grow in size and then collapse abruptly with 
the release of energy at enormous rate, thus increasing the local temperature and pressure. ${ }^{15}$ As a consequence, greater penetration of the solvent into seed materials occurs, leading to a more extensive release of oil into the solvent. ${ }^{16} \mathrm{C}$. inophyllum seed oil has been extracted using conventional mechanical pressing and solvent extraction techniques. However, oil extraction from C. inophyllum seeds using UAE technique has not been investigated so far.

Kinetic models have been used widely in the extraction process of natural substances. The Power Law and Parabolic Diffusion models were used in the ultrasound-assisted extraction of water-soluble components and polysaccharides from medicinal fungi. ${ }^{17}$ Meanwhile, Unsteady Diffusion and Peleg's models were used to modelled the ultrasonic extraction of oil from tobacco and ursolic acid from Ocimum Sanctum, respectively. ${ }^{18,19}$

The kinetics of oil extraction process have also been modelled using a two parametric mathematical model, namely Patricelli's model, proposed by Xi et al. ${ }^{20}$ It is used to explain the kinetics of oil extraction from black seeds and olive cake. ${ }^{21,22}$ This mathematical model is applied based on two extraction steps, which are the washing and diffusion stages. During the washing stage, the oil on the solid surface and broken cells is rapidly extracted by simple washing with the solvent. Meanwhile, during the diffusion stage, the remaining oil entrapped in the internal site of intact cells is removed by diffusion from within the solid particles to the solvent. ${ }^{20}$ From an engineering point of view, the knowledge gain in kinetics study of a process are highly beneficial for scaling up and industrial processing purposes. Nonetheless, the kinetics of UAE of $C$. inophyllum seeds oil is still scarce in the literature.

The present study deals with UAE of oil from C. inophyllum seeds. The main objectives of this study is to examine the applicability of Patricelli's mathematical model in describing the kinetics behaviour of UAE of $C$. inophyllum seeds oil as well as to determine the influence of ultrasonic power, extraction temperature and liquid to solid (L/S) ratio on oil yield.

\section{EXPERIMENTAL}

\subsection{Materials}

Mature C. inophyllum fruits were collected from the ground under the tree located in Taman Kerian, Parit Buntar, Perak, Malaysia. The species was identified in Herbarium Unit, School of Biological Sciences, Universiti Sains Malaysia (USM 
Herbarium 11565). The fruits were cleaned and stored at ambient temperature. Prior to oil extraction, the fruits were manually cracked to obtain the seeds. The seeds were selected according to their condition; only good-conditioned seeds were used while damaged seeds were discarded. Then, the cleaned seeds were ground using a dry mill and sieved through a 10 -mesh sieve (pore size $2 \mathrm{~mm}$ ) shaker. The seeds sample with particle size of $2 \mathrm{~mm}$ and below was used in this study. $n$-hexane (Merck) was used as a solvent.

\subsection{Ultrasound-assisted Extraction}

An ultrasonic water bath (Transsonic Digital S Model T840DH) was used for indirect ultrasonication. It has an internal tank dimension of $327 \mathrm{~mm}, 300 \mathrm{~mm}$ and $200 \mathrm{~mm}$, volume of $18 \mathrm{~L}$, power consumption of $1100 \mathrm{~W}$ and a fixed operating frequency of $40 \mathrm{kHz}$. The ultrasonic bath was equipped with a timer, heater, temperature regulator and indicator, as well as ultrasound power regulator (70-250 W). The bath was filled with distilled water approximately $2 / 3$ of its volume (about $12 \mathrm{~L}$ ). During extraction, the temperature was controlled and maintained at the desired level by circulating distilled water through the ultrasonic bath by using a thermo-circulator water bath. The seeds sample $(5 \mathrm{~g})$ and extracting solvent, $n$-hexane were mixed in an Erlenmayer flask $(250 \mathrm{ml})$, which was then covered with aluminium foil. The flask was immediately immersed in the ultrasonic bath and fixed at the center position for each experimental run. After the extraction process was completed, the mixture was centrifuged at $4,000 \mathrm{rpm}$ for $20 \mathrm{~min}$ to separate the liquid extract from the solid residue. Subsequently, the solvent was removed from the liquid extract using a rotary evaporator (Heidolph). The extracted oil obtained were placed in a desiccator to remove any moisture and weighed until a constant weight was reached. In this study, the ultrasonic power, extraction temperature as well as $\mathrm{L} / \mathrm{S}$ ratio were varied from $190-230 \mathrm{~W}, 35^{\circ} \mathrm{C}-45^{\circ} \mathrm{C}$ and $15-25 \mathrm{ml} / \mathrm{g}$ respectively. These range were chosen based on the preliminary study.

\subsection{Determination of $C$. inophyllum Oil Yield}

Extraction yield of C. inophyllum oil was calculated using Equation 1:

$$
Y=\frac{M_{1}}{M_{0}} \times 100 \%
$$

where $Y$ is the extraction yield of $C$. inophyllum oil (\%), $M_{1}$ is the mass of C. inophyllum oil extracted from the sample $(\mathrm{g})$ and $M_{0}$ is the mass of the seeds sample used (g). ${ }^{23}$ 


\subsection{Mathematical Model}

Patricelli's model is expressed in Equation 2:

$C_{t}=C_{1}\left(1-\exp \left(-k_{1} t\right)\right)+C_{2}\left(1-\exp \left(-k_{2} t\right)\right)$

where $C_{t}$ is the oil yield (\%), $C_{I}$ is the oil yield at equilibrium for the washing step (\%), $C_{2}$ is the oil yield at equilibrium for the diffusion step (\%), $k_{1}$ is the mass transfer coefficient for the washing step $\left(\mathrm{min}^{-1}\right), k_{2}$ is the mass transfer coefficient for the diffusion step $\left(\mathrm{min}^{-1}\right)$ and $t$ is the time (min). According to Velickovic et al., for an extraction curve, the two stages involved in extraction was distinguished in such a way that the washing stage was characterised by a rapid increase in the extraction yield while the slow diffusion stage was characterised by a slow increase in the extraction yield. ${ }^{24}$ The values of oil yield at equilibrium, $C_{l}$ and $C_{2}$ as well as the mass transfer coefficient, $k_{1}$ and $k_{2}$ were calculated numerically with a non-linear regression using Polymath Software 5.10.

\subsection{Statistical Analysis}

The validation of Patricelli's model was done by evaluating the differences between the experimental and predicted oil yield via determination coefficient, $R^{2}$. In addition, the goodness-of-fit of the model was further evaluated using the mean relative percentage deviation (MRPD) value. It is defined in Equation 3:

$\operatorname{MRPD}(\%)=\frac{100}{\mathrm{~N}} \times \sum \frac{\left|\mathrm{Y}-\mathrm{Y}_{\mathrm{p}}\right|}{\mathrm{Y}}$

where $\mathrm{Y}$ and $\mathrm{Y}_{\mathrm{P}}$ are the experimental and predicted yield of C. inophyllum seeds oil respectively, and $\mathrm{N}$ is the number of experimental data. A mathematical model is considered acceptable to be used in describing an extraction process if the MRPD value is less than $10 \% .{ }^{25}$

\section{RESULTS AND DISCUSSION}

The profiles of experimental (represented by symbols) and simulated (represented by lines) oil yield for three different levels of ultrasonic power is shown in Figure 2. It can be seen that the oil yield increased rapidly with ultrasonic power during the washing period at the early beginning of the process from $1 \mathrm{~min}$ until $10 \mathrm{~min}$ whereas a slow increase in the oil yield was observed during the diffusion period, approximately after $10 \mathrm{~min}$ of extraction time. The coefficients of kinetic model 
which were determined from the experimental data are shown in Table 1. The high values of determination coefficient $\left(R^{2} \geq 0.994\right)$ for each ultrasonic power indicated that the experimental data fit the model very well. In fact, the MRPD values ranging from $0.439 \%-0.742 \%$ shows that the model is acceptable to be used in describing the extraction of oil from C. inophyllum seeds.

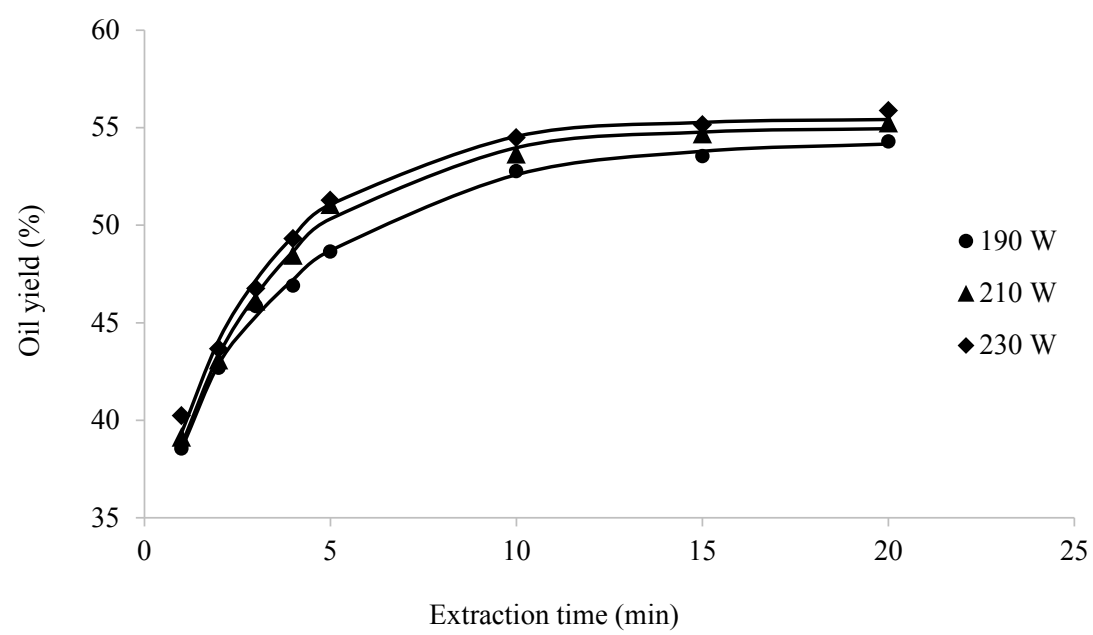

Figure 2: Effect of different ultrasonic power on kinetics of oil extraction from C. inophyllum seeds (condition: $n$-hexane as a solvent, extraction temperature $40^{\circ} \mathrm{C}$ and $\mathrm{L} / \mathrm{S}$ ratio $20 \mathrm{ml} / \mathrm{g}$ ).

Table 1: The oil yields at equilibrium and mass transfer coefficients for different ultrasonic power.

\begin{tabular}{cccccccc}
\hline & \multicolumn{2}{c}{$\begin{array}{c}\text { Oil yield at } \\
\text { Ultrasonic power }(\mathrm{W})\end{array}$} & \multicolumn{2}{c}{$\begin{array}{c}\text { Mass transfer } \\
\text { equilibrium (\%) }\end{array}$} & \multicolumn{2}{c}{ coefficient $\left(\mathrm{min}^{-1}\right)$} & \multirow{2}{*}{ MRPD (\%) } \\
\cline { 2 - 5 } & $\mathrm{C}_{1}$ & $\mathrm{C}_{2}$ & $\mathrm{k}_{1}$ & $\mathrm{k}_{2}$ & & \\
\hline 190 & 36.115 & 18.208 & 3.248 & 0.235 & 0.998 & 0.439 \\
210 & 33.618 & 21.379 & 4.232 & 0.304 & 0.995 & 0.686 \\
230 & 34.131 & 21.333 & 4.151 & 0.316 & 0.994 & 0.742 \\
\hline
\end{tabular}

The values of oil yield at equilibrium for washing stage $\left(\mathrm{C}_{1}\right)$ were always higher than that for diffusion stage $\left(\mathrm{C}_{2}\right)$ for all ultrasonic power levels, indicating that most of the oil was extracted during the washing stage. This is because, during the washing stage, the oil from the outer surface of the seeds readily dissolve into the extracting solvent. Meanwhile, during the diffusion stage, the oil diffuse from the intact seed cells into the solvent. As the ultrasonic power increases from $190 \mathrm{~W}$ to $210 \mathrm{~W}$, the equilibrium oil yield for washing stage decreased while the 
equilibrium oil yield for diffusion stage increased. This observation may imply that ultrasonic power had a greater effect during the diffusion stage than the washing stage. The enhancement of oil yield during the diffusion stage could be due to the greater mechanical effects of ultrasound which is responsible for the efficient cell disruption of the seeds that leads to a more effective mass transfer of the oil into the solvent system. ${ }^{26}$

However, beyond $210 \mathrm{~W}$, the equilibrium oil yield for washing stage increased slightly and the equilibrium oil yield for diffusion stage did not show any significant changes. A higher ultrasonic power would cause an increase in the bubble numbers in the solvent during cavitation. This might decrease the efficiency of the ultrasound energy transmitted into the medium and as a result, the oil yield would no longer increase. ${ }^{27}$ The mass transfer coefficient for washing $\left(\mathrm{k}_{1}\right)$ increased when the ultrasonic power was raised from $190 \mathrm{~W}$ to $210 \mathrm{~W}$ but thereafter decreased slightly while the mass transfer coefficient for diffusion stage $\left(\mathrm{k}_{2}\right)$ increased with increasing ultrasonic power. These results reveal that oil extraction occurs at a higher rate as the ultrasonic power increases. The formation of more cavitation bubbles at a higher ultrasonic power accelerates the penetration of solvent into the cells and the release of oil from the cells into the solvent, hence improving the mass transfer rate..$^{28}$

The influence of extraction temperature on oil yield was studied between $35^{\circ} \mathrm{C}$ and $45^{\circ} \mathrm{C}$ at a fixed ultrasonic power of $210 \mathrm{~W}$ and the results are shown in Figure 3. A positive relationship between the extraction temperature and oil yield is observed for all temperature levels. The oil yields showed a rapid increment with temperature during the initial stage of extraction and slowed down as the extraction time was extended beyond $10 \mathrm{~min}$.

The values of kinetic model parameters are shown in Table 2. It can be seen that the experimental data obtained at all extraction temperatures fit well into the kinetic model ranging from 0.982 to 0.992 . The MRPD values for each temperature $(0.907 \%-1.205 \%)$ which were below $10 \%$ confirmed that the kinetic model is adequate to represent the oil extraction process. It was observed that between $35^{\circ} \mathrm{C}$ and $40^{\circ} \mathrm{C}$, the oil yield at equilibrium for washing stage $\left(\mathrm{C}_{1}\right)$ did not show any changes while the oil yield at equilibrium for diffusion stage $\left(\mathrm{C}_{2}\right)$ increases. This might be because temperature had a smaller effect on the extraction mechanism during the washing stage, as compared to the diffusion stage. The increment of $\mathrm{C}_{2}$ during the latter stage was due to the higher intensity of acoustic cavitation caused by a higher temperature which assisted in the cell wall breaking in order to release oil into the solvent medium. ${ }^{29}$ 


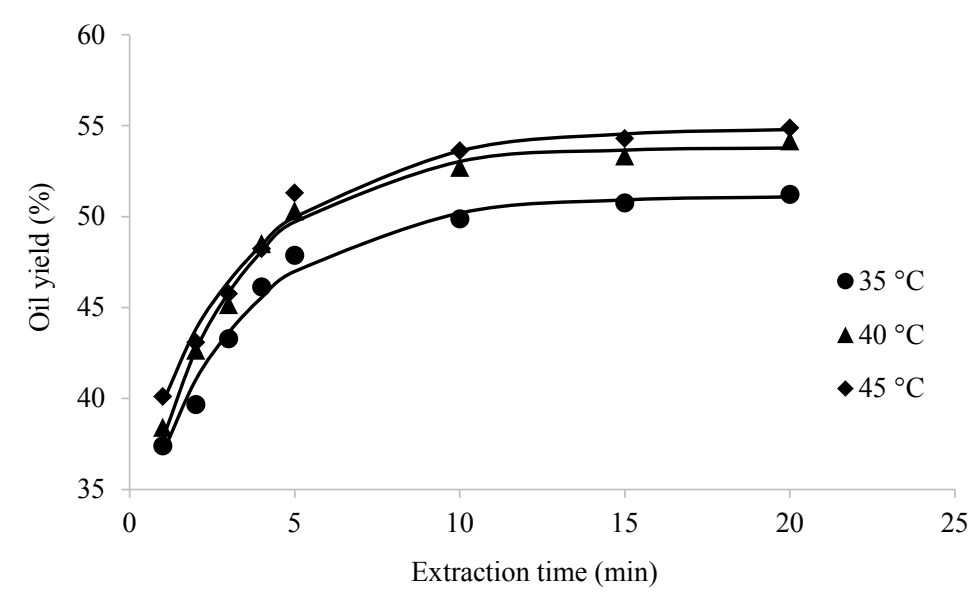

Figure 3: Effect of different extraction temperature on kinetics of oil extraction from C. inophyllum seeds (condition: $n$-hexane as a solvent, ultrasonic power $210 \mathrm{~W}$ and $\mathrm{L} / \mathrm{S}$ ratio $20 \mathrm{ml} / \mathrm{g}$ ).

Table 2: The oil yields at equilibrium and mass transfer coefficients for different extraction temperature.

\begin{tabular}{ccccccc}
\hline \multirow{2}{*}{$\begin{array}{l}\text { Extraction } \\
\text { temperature }\left({ }^{\circ} \mathrm{C}\right)\end{array}$} & \multicolumn{2}{c}{$\begin{array}{c}\text { Oil yield at } \\
\text { equilibrium }(\%)\end{array}$} & \multicolumn{2}{c}{$\begin{array}{c}\text { Mass transfer coefficient } \\
\left(\mathrm{min}^{-1}\right)\end{array}$} & \multirow{2}{*}{ MRPD (\%) } \\
\cline { 2 - 5 } & $\mathrm{C}_{1}$ & $\mathrm{C}_{2}$ & $\mathrm{k}_{1}$ & $\mathrm{k}_{2}$ & & \\
\hline 35 & 32.840 & 18.286 & 4.091 & 0.297 & 0.982 & 1.205 \\
40 & 32.051 & 21.755 & 4.212 & 0.334 & 0.992 & 0.907 \\
45 & 35.829 & 19.044 & 4.101 & 0.272 & 0.986 & 0.961 \\
\hline
\end{tabular}

$\mathrm{C}_{1}$ increases when the temperature was raised further to $45^{\circ} \mathrm{C}$. This was due to the changes of physical properties of the oil and solvent including the solubility and viscosity. A higher extraction temperature resulted in a higher solubility of oil in the extracting solvent as well as a lower viscosity of the solvent, therefore improving the mass transfer of the oil..$^{30,31}$ Meanwhile, the reduction of $\mathrm{C}_{2}$ at $45^{\circ} \mathrm{C}$ was due to the higher vapour pressure at elevated temperature which assisted in the formation of vapour-filled bubbles and as a result, the implosion of cavitation bubbles would be cushioned. This phenomenon, known as the cushioning effect, would eventually cause the ultrasound cavitation effect to be less efficient. ${ }^{32}$

The mass transfer coefficients $\left(\mathrm{k}_{1}\right.$ and $\left.\mathrm{k}_{2}\right)$ increased with increasing temperature but reduced when the temperature was raised to $45^{\circ} \mathrm{C}$. This is because when the temperature is too high, a larger amount of bubbles were formed but unfortunately, 
they collapse with less intensity. An increase in temperature have also caused a decrease in the surface tension of the extracting solvent. A lower surface tension affects the bubble formation and collapse. As a result, the cavitation effect was less effective, thus causing a decrease in the mass transfer rate. ${ }^{33}$

Figure 4 presents the effect of $\mathrm{L} / \mathrm{S}$ ratio on $C$. inophyllum oil yield while ultrasonic power and extraction temperature were $210 \mathrm{~W}$ and $45^{\circ} \mathrm{C}$, respectively. The yield of $C$. inophyllum oil increased sharply with the increase of $\mathrm{L} / \mathrm{S}$ ratio throughout the first $10 \mathrm{~min}$ of extraction period and the increase become less significant as the extraction proceeded. The corresponding values of kinetic model coefficients for $\mathrm{L} / \mathrm{S}$ ratio $15 \mathrm{ml} / \mathrm{g}, 20 \mathrm{ml} / \mathrm{g}$ and $25 \mathrm{ml} / \mathrm{g}$ are shown in Table 3 . A high values of determination coefficient were obtained for all L/S ratio $(0.974,0.999)$, indicating a satisfactory fit of the experimental oil yield with the kinetic model. Additionally, MRPD values of less than $10 \%$ for every $\mathrm{L} / \mathrm{S}$ ratio implies that the kinetic model can describe the extraction process well. It can be seen that the oil yield at equilibrium for washing stage $\left(\mathrm{C}_{1}\right)$ and diffusion stage $\left(\mathrm{C}_{2}\right)$ increased with increasing $\mathrm{L} / \mathrm{S}$ ratio. However, the oil yield at equilibrium for diffusion stage $\left(\mathrm{C}_{2}\right)$ decreased as the ratio was increased to $25 \mathrm{ml} / \mathrm{g}$. The increment of oil yield with the increase of solvent quantity was due to a greater driving force which caused by a larger concentration difference between the interior cells and surrounding solvent medium. ${ }^{34}$

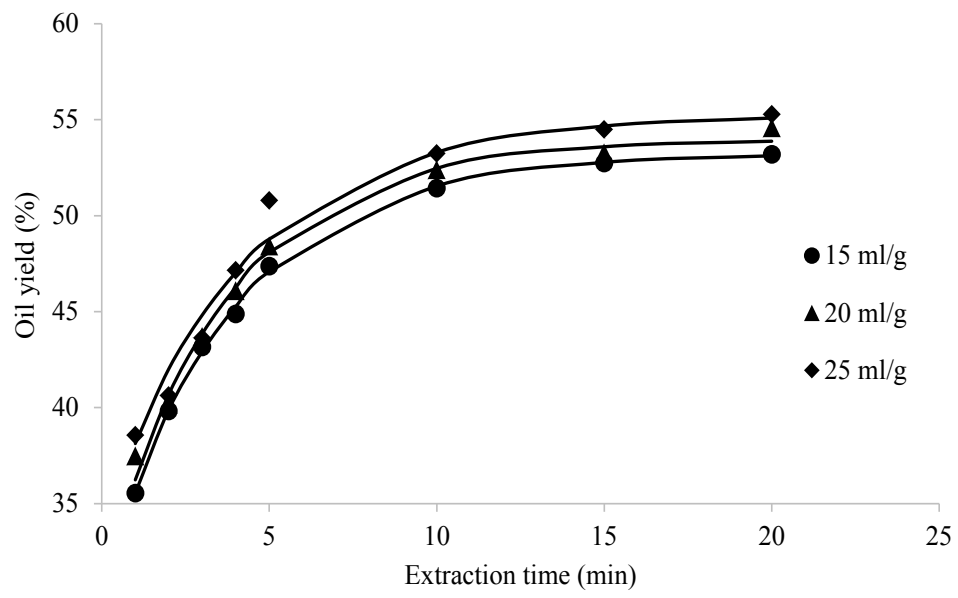

Figure 4: Effect of different L/S ratio on kinetics of oil extraction from C. inophyllum seeds (condition: $n$-hexane as a solvent, ultrasonic power $210 \mathrm{~W}$ and extraction temperature $\left.45^{\circ} \mathrm{C}\right)$. 
Table 3: The oil yields at equilibrium and mass transfer coefficients for different L/S ratio.

\begin{tabular}{ccccccc}
\hline \multirow{2}{*}{$\begin{array}{c}\mathrm{L} / \mathrm{S} \text { ratio } \\
(\mathrm{ml} / \mathrm{g})\end{array}$} & $\begin{array}{c}\text { Oil yield at equilibrium } \\
(\%)\end{array}$ & \multicolumn{2}{c}{$\begin{array}{c}\text { Mass transfer coefficient } \\
\left(\mathrm{min}^{-1}\right)\end{array}$} & \multicolumn{2}{c}{ MRPD (\%) } \\
\cline { 2 - 5 } & $\mathrm{C}_{1}$ & $\mathrm{C}_{2}$ & $\mathrm{k}_{1}$ & $\mathrm{k}_{2}$ & & \\
\hline 15 & 30.92 & 22.325 & 4.248 & 0.257 & 0.999 & 0.326 \\
20 & 31.123 & 22.861 & 4.585 & 0.271 & 0.991 & 1.013 \\
25 & 33.952 & 21.319 & 4.616 & 0.238 & 0.974 & 1.533 \\
\hline
\end{tabular}

Meanwhile, an increase of L/S ratio also increases both mass transfer coefficients for washing and diffusion stage $\left(\mathrm{k}_{1}\right.$ and $\left.\mathrm{k}_{2}\right)$. Nevertheless, beyond $\mathrm{L} / \mathrm{S}$ ratio of 20 $\mathrm{ml} / \mathrm{g}$, an increase in mass transfer coefficient for diffusion stage $\left(\mathrm{k}_{2}\right)$ was no longer observed. This might indicates that a hexane volume of $100 \mathrm{ml}$ was sufficient for the oil extraction process. Furthermore, excessive amount of solvent would not improve the driving force any further. ${ }^{35}$

\section{CONCLUSION}

In this study, the kinetics of UAE of oil from $C$. inophyllum seeds was evaluated using Patricelli's mathematical model. The results showed that this model was suitable to be used in modelling the extraction process at tested conditions with high values of determination coefficient $\left(0.974 R^{2}, 0.999\right)$ and low MRPD values $(0.326 \%, P 1.533 \%)$. The model coefficients were calculated accordingly using the experimental data. The results obtained showed that more oil was extracted into the solvent medium during the washing stage and the oil extraction rate was higher during the washing stage, as compared to the diffusion stage. The oil yield increased with increasing ultrasonic power, extraction temperature as well as L/S ratio.

\section{ACKNOWLEDGEMENTS}

The authors gratefully acknowledge Universiti Sains Malaysia for the financial support of this study, and also a scholarship (MyMaster) from the Ministry of Education Malaysia for the first author. The authors would also like to thank Ministry of Higher Education of Malaysia (MOHE) for funding this work through Fundamental Research Grant Scheme (203/PJKIMIA/6071270). 


\section{REFERENCES}

1. Chavan, S. B., Kumbhar, R. R. \& Deshmukh, R. B. (2013). Callophyllum inophyllum Linn ("honne") oil, a source for biodiesel production. Res. J. Chem. Sci., 3(11), 24-31.

2. Ha, M. H. et al. (2009). Antimicrobial activity of Calophyllum inophyllum crude extracts obtained by pressurized liquid extraction. Asian J. Trad. Med., 4(4), 141-146.

3. Hien, H. M. et al. (2011). Development and validation of a GC-MS method for rapid determination of calophyllolide in Calophyllum inophyllum L.: A quality control approach. Chin. J. Nat. Med., 9(6), 429-434.

4. Ong, H. C. et al. (2011). Comparison of palm oil, Jatropha curcas and Calophyllum inophyllum for biodiesel: A review. Renew. Sust. Energ Rev., 15(8), 3501-3515, https://doi.org/10.1016/j.rser.2011.05.005.

5. Rizwanul Fattah, I. M. etal.(2014). Experimental investigation of performance and regulated emissions of a diesel engine with Calophyllum inophyllum biodiesel blends accompanied by oxidation inhibitors. Energ. Convers. Manage., 83, 232-240, https://doi.org/10.1016/j.enconman.2014.03.069.

6. Lawal, O. S. et al. (2010). Equilibrium, thermodynamic and kinetic studies for the biosorption of aqueous lead(II) ions onto the seed husk of Calophyllum inophyllum. J. Hazard. Mater., 177(1-3), 829-835, https://doi. org/10.1016/j.jhazmat.2009.12.108.

7. Ajayi, I. A. et al. (2008). Short-term toxicological evaluation of Terminalia catappa, Pentaclethra macrophylla and Calophyllum inophyllum seed oils in rats. Food Chem., 106(2), 458-465, https://doi.org/10.1016/j. foodchem.2007.05.093.

8. Thengane, S. R. et al.(2006). Micropropagation of Indian laurel (Calophyllum inophyllum), a source of anti-HIV compounds. Curr. Sci., 90,(10), 13931397.

9. Venkanna, B. K. \& Venkataramana, R. C. (2009). Biodiesel production and optimization from Calophyllum inophyllum linn oil (honne oil) - A three stage method. Biores. Technol., 100(21), 5122-5125, https://doi. org/10.1016/j.biortech.2009.05.023.

10. Sayyar, S., Abidin, Z. Z. \& Yunus, R. (2013). Optimisation of solid liquid extraction of jatropha oil using petroleum ether. Asia-Pac. J. Chem. Eng., 8(3), 331-338, https://doi.org/10.1002/apj.1664.

11. Jovanovic-Malinovska, R., Kuzmanova, S. \& Winkelhausen, E. (2015). Application of ultrasound for enhanced extraction of prebiotic oligosaccharides from selected fruits and vegetables. Ultrason. Sonochem., 22(0), 446-453, https://doi.org/10.1016/j.ultsonch.2014.07.016. 
12. Lin, J.-Y. et al. (2012). Ultrasonic extraction of hempseed oil. J. Food Process. Eng., 35(1), 76-90, https://doi.org/10.1111/j.1745-4530.2010.00601.x.

13. Samaram, S. H. et al. (2013). Ultrasound-assisted extraction (UAE) and solvent extraction of papaya seed oil: Yield, fatty acid composition and triacylglycerol profile. Molecules, 18(0), 12474-12487.

14. Kamazani, N. A. et al. (2014). Evaluation and analysis of the ultrasoundassisted extracted tomato seed oil. J. Food Biosci. Technol., 4(2), 57-66.

15. Fontana, A. R. et al. (2010). Ultrasound-assisted leaching-dispersive solid-phase extraction followed by liquid-liquid microextraction for the determination of polybrominated diphenyl ethers in sediment samples by gas chromatography-tandem mass spectrometry. Talanta, 82(1), 359-366, https://doi.org/10.1016/j.talanta.2010.04.050.

16. Pongmalai, P. et al. (2015). Enhancement of microwave-assisted extraction of bioactive compounds from cabbage outer leaves via the application of ultrasonic pretreatment. Sep. Purif. Technol., 144(0), 37-45, https://doi. org/10.1016/j.seppur.2015.02.010.

17. Cheung, Y.-C., Siu, K.-C. \& Wu, J.-Y. (2013). Kinetic models for ultrasoundassisted extraction of water-soluble components and polysaccharides from medicinal fungi. Food Bioprocess. Tech., 6(10), 2659-2665, https://doi. org/10.1007/s11947-012-0929-z.

18. Stanisavljević, I. T., Lazić, M. L. \& Veljković, V. B. (2007). Ultrasonic extraction of oil from tobacco (Nicotiana tabacum L.) seeds. Ultrason. Sonochem., 14(5), 646-652, https://doi.org/10.1016/j.ultsonch.2006.10.003.

19. Vetal, M. D., Lade, V. G. \& Rathod, V. K. (2013). Extraction of ursolic acid from Ocimum sanctum by ultrasound: Process intensification and kinetic studies. Chem. Eng. Process.: Process Intensif., 69(0), 24-30, https://doi. org/10.1016/j.cep.2013.01.011.

20. Xi, J., He, L. \& Yan, L. (2015). Kinetic modeling of pressure-assisted solvent extraction of polyphenols from green tea in comparison with the conventional extraction. Food Chem., 166(0), 287-291, https://doi. org/10.1016/j.foodchem.2014.06.026.

21. Abdullah, M. \& Koc, A. B. (2013). Kinetics of ultrasound-assisted oil extraction from black seed (Nigella sativa). J. Food Process. Pres., 37(5), 814-823.

22. Amarni, F. \& Kadi, H. (2010). Kinetics study of microwave-assisted solvent extraction of oil from olive cake using hexane: Comparison with the conventional extraction. Innov. Food Sci. Emerg. Technol., 11(2), 322-327, https://doi.org/10.1016/j.ifset.2010.01.002.

23. Hu, A. J. et al. (2010). Kinetic model and technology of ultrasound extraction of safflower seed oil. J. Food Process Eng., 35(2), 278-294, https://doi. org/10.1111/j.1745-4530.2010.00589.x. 
24. Velickovic, D. T. et al. (2006). Kinetics of ultrasonic extraction of extractive substances from garden (Salvia officinalis L.) and glutinous (Salvia glutinosa L.) sage. Ultrason. Sonochem., 13(0), 150-156, https://doi.org/10.1016/j. ultsonch.2005.02.002.

25. Kaymak-Ertekin, F. \& Gedik, A. (2004). Sorption isotherms and isosteric heat of sorption for grapes, apricots, apples and potatoes. LWT Food Sci. Technol., 37(4), 429-438, https://doi.org/10.1016/j.lwt.2003.10.012.

26. Liu, Y. et al. (2015). Optimization of ultrasonic extraction of polysaccharides from Hovenia dulcis peduncles and their antioxidant potential. Int. J. Biol. Macromol., 80(0), 350-357, https://doi.org/10.1016/j.ijbiomac.2015.06.054.

27. Peyman, P. G. (2015). Modeling and optimization of ultrasound-assisted extraction of polysaccharide from the roots of Althaea officinalis. J. Food Process. Pres., https://doi.org/10.1111/jfpp.12454.

28. Gholivand, M. B., Yamini, Y. \& Dayeni, M. (2014). Optimization and comparison of ultrasound-assisted extraction of estragole from Tarragon leaves with hydro-distillation method. Anal. Bioanal. Chem. Res., 1(2), 99107.

29. Teh, S.-S. \& Birch, E. J. (2014). Effect of ultrasonic treatment on the polyphenol content and antioxidant capacity of extract from defatted hemp, flax and canola seed cakes. Ultrason. Sonochem., 21(1), 346-353, https:// doi.org/10.1016/j.ultsonch.2013.08.002.

30. Zou, T.-B. et al. (2011). Optimization of ultrasound-assisted extraction of anthocyanins from mulberry, using response surface methodology. Int. J. Mol. Sci., 12(0), 3006-3017, https://doi.org/10.3390/ijms12053006.

31. Wei, M.-C. \& Yang, Y.-C. (2014). Extraction characteristics and kinetic studies of oleanolic and ursolic acids from Hedyotis diffusa under ultrasoundassisted extraction conditions. Sep. Purif. Technol., 130(0), 182-192, https:// doi.org/10.1016/j.seppur.2014.04.029.

32. Lou, Z. et al. (2010). Improved extraction of oil from chickpea under ultrasound in a dynamic system. J. Food Eng., 98(1), 13-18, https://doi. org/10.1016/j.jfoodeng.2009.11.015.

33. Charpe, T. W. \& Rathod, V. K. (2014). Effect of ethanol concentration in ultrasound assisted extraction of glycyrrhizic acid from licorice root. Iran J. Chem. Eng., 11(4), 21-30.

34. Bulduk, I., Gezer, B. \& Cengiz, M. (2015). Optimization of ultrasoundassisted extraction of morphine from capsules of Papaver somniferum by response surface methodology. Int. J. Anal. Chem., 2015(0), 1-9, https://doi. org/10.1155/2015/796349.

35. Gutte, K. B., Sahoo, A. K. \& Ranveer. (2015). Effect of ultrasonic treatment on extraction and fatty acid profile of flaxseed oil. $O C L, 22(5), 1-7$, https:// doi.org/10.1051/ocl/2015038. 